\title{
Evaluasi Ex Ante Kebijakan Dana Khusus Kepulauan (DKK) terhadap Ketimpangan Alokasi Transfer ke Daerah
}

\author{
Luthfi Muhamad Iqbal ${ }^{1}$
}

\section{Afiliasi}

${ }^{1}$ Calon Perencana Pertama di Direktorat Perkotaan Perumahan dan Permukiman Kementerian Perencanaan Pembangunan Nasional/Bappenas Republik Indonesia

Korespondensi: luthfi.iqbal23@gmail.com

\begin{abstract}
Abstrak
Upaya afirmasi pembangunan bagi daerah kepulauan telah didorong oleh berbagai pihak, reorientasi paradigma pembangunan dalam mewujudkan poros maritim dunia ditempuh salah satunya melalui inisiatif RUU Daerah Kepulauan yang diusung oleh DPD. Salah satu butir utama dalam regulasi tersebut ialah terkait Dana Khusus Kepulauan (DKK) sebagai penerimaan baru bagi daerah kepulauan untuk mempercepat pembangunan daerah kepulauan. Pada tulisan ini akan dibahas dampak kebijakan DKK terhadap ketimpangan alokasi dana transfer antardaerah. Untuk menjawab tujuan, ditelusuri definisi daerah kepulauan, persoalan saat ini, konsep DKK yang diajukan serta pengaruh DKK pada ketimpangan alokasi Transfer ke Daerah dan Dana Desa (TKDD). Penelitian ini merupakan penelitian evaluasi ex-ante dengan pendekatan with-versus-without comparison dan menggunakan metode penelitian campuran antara kualitatif yakni analisis konten regulasi dan literatur, serta kuantitatif deskriptif dengan memanfaatkan data sekunder yang tersedia. Hasil temuan evaluasi ini ialah masih terdapat persoalan dalam mendefinisikan daerah kepulauan terutama kriteria gugusan pulau dan kesatuan sosial budaya ekonomi dan geografis, serta adanya batasan kewenangan urusan pemerintahan di bidang kelautan yang hanya diberikan kepada pemerintahan provinsi. Selain itu kinerja daerah kepulauan berbeda-beda pula tergantung karakteristik geografis, fisik dan administratif daerah, sehingga tantangan, persoalah, yang ditangani tidak seragam antardaerah kepulauan. Sebaliknya, berdasarkan hasil analisis justru yang terlihat jelas ialah ketimpangan jawa-non jawa, barat Indonesia dan timur Indonesia serta perkotaan dan perdesaan. Kesimpulannya adalah dengan skenario DKK yang diperoleh dari 5\% DTU nasional akan meningkatkan kesenjangan alokasi sebesar 25.12\% apabila DKK dialokasikan pada daerah kepulauan BKSDK (8 wilayah). Jika DKK ditransfer ke seluruh daerah kepulauan yang memenuhi kriteria maka ketimpangan alokasi meningkat hingga 40.66\%. Konvergensi DAK Tematik Kepulauan dan eksplorasi pembiayaan kreatif yang berbasis kelautan (marine based financing) dapat dipertimbangkan untuk mewujudkan percepatan pembangunan daerah kepulauan.
\end{abstract}

Kata Kunci: daerah kepulauan; dana khusus kepulauan; evaluasi ex ante.

Doi: https://doi.org/10.47266/bwp.v3i2.78 | halaman: 218-237

Dikirim pada: 25 Juli 2020. Diterima pada: 28 August 2020. Dipublikasikan pada: 07 September 2020 


\section{Pendahuluan}

Upaya afirmasi pembangunan bagi daerah kepulauan telah didorong oleh berbagai pihak termasuk Dewan Perwakilan Daerah (DPD). Pada 17 Desember 2019 DPD telah mengusulkan kembali Rancangan UndangUndang (RUU) tentang Daerah Kepulauan ke dalam Program Legislasi Nasional (Prolegnas) Prioritas Tahun 2020 (DPR RI, 2020). Salah satu butir utama dalam usulan RUU tersebut ialah adanya usulan mengenai Dana Khusus Kepulauan (DKK) (DPD RI, 2019) yang pada draf terakhir, disebut sebagai penerimaan Daerah Kepulauan dalam rangka percepatan pembangunan (DPR RI, 2020).

Argumentasi utama yang melandasi usulan DKK sebagai alokasi transfer baru bagi daerah kepulauan ialah untuk memastikan laju perkembangan pembangunan daerah yang berimbang antara daerah kepulauan dengan daerah daratan, termasuk memperkuat konektivitas kepulauan dengan daerah daratan, percepatan pemenuhan SPM dan meningkatkan ketangguhan daerah kepulauan terhadap ancaman bencana alam serta perubahan iklim. Badan Kerja Sama Daerah Kepulauan (BKSDK) yang terdiri dari 8 Provinsi yaitu Maluku, Maluku Utara, Nusa Tenggara Barat, Nusa Tenggara Timur, Kepulauan Bangka Belitung, Kepulauan Riau, Sulawesi Utara dan Sulawesi Tenggara (Kelen, 2017) sangat mendukung direalisasikannya kebijakan DKK dalam RUU ini (Ismail, 2018).

Pada naskah akademik RUU telah diuraikan bagaimana DKK dapat menutup gap kemampuan keuangan antara daerah kepulauan dan daerah bukan kepulauan. Namun belum dibahas mengenai bagaimana dampaknya terhadap ketimpangan alokasi dana transfer ke daerah dan dana desa secara keseluruhan. Dalam tulisan ini akan dilakukan evaluasi ex-ante dampak kebijakan Dana Khusus Kepulauan terhadap ketimpangan alokasi Dana Transfer antardaerah, baik menurut skenario dalam Naskah Akademik RUU maupun draf RUU terbaru. Tulisan ini diharapkan dapat memberikan kontribusi bagi penyusunan RUU tentang Percepatan Pembangunan Daerah Kepulauan khususnya pertimbangan mengenai dana khusus kepulauan/penerimaan daerah kepulauan dalam rangka percepatan pembangunan.

\section{Metodologi}

Penelitian ini adalah penelitian Evaluasi Ex Ante, yakni evaluasi kebijakan yang dilakukan sebelum kebijakan ditetapkan dan diimplementasikan untuk memberikan penilaian awal dan mengantisipasi mengenai perkiraan dampak serta konsekuensi yang dihasilkan dari implementasi kebijakan (Wollmann, 2007). Pendekatan dasar evaluasi yang digunakan ialah with ws without comparison yakni membandingkan skenario antara dengan atau tanpa intervensi kebijakan dengan menggunakan metode penelitian campuran (mix method).

Ruang lingkup penelitian ialah mengenai Dana Khusus Kepulauan dalam konstelasi perimbangan keuangan antarpemerintah pusat dan daerah, beserta parameter-parameter yang digunakan untuk menghasilkan gambaran kondisi daerah kepulauan. Cakupan wilayah penelitian meliputi 542 daerah otonom provinsi, kabupaten, kota di Indonesia dengan fokus pada daerah-daerah kepulauan sesuai definisi yang akan dibahas pada tulisan ini. Teknik pengumpulan data dilakukan dengan dua cara yakni melalui pengumpulan dokumen pustaka teori, regulasi, dan kebijakan dan pengumpulan data sekunder dari berbagai sumber elektronik. Kerangka berpikir, data, analisis yang digunakan, serta pertanyaan penelitian evaluasi dapat dilihat pada Gambar 1: 


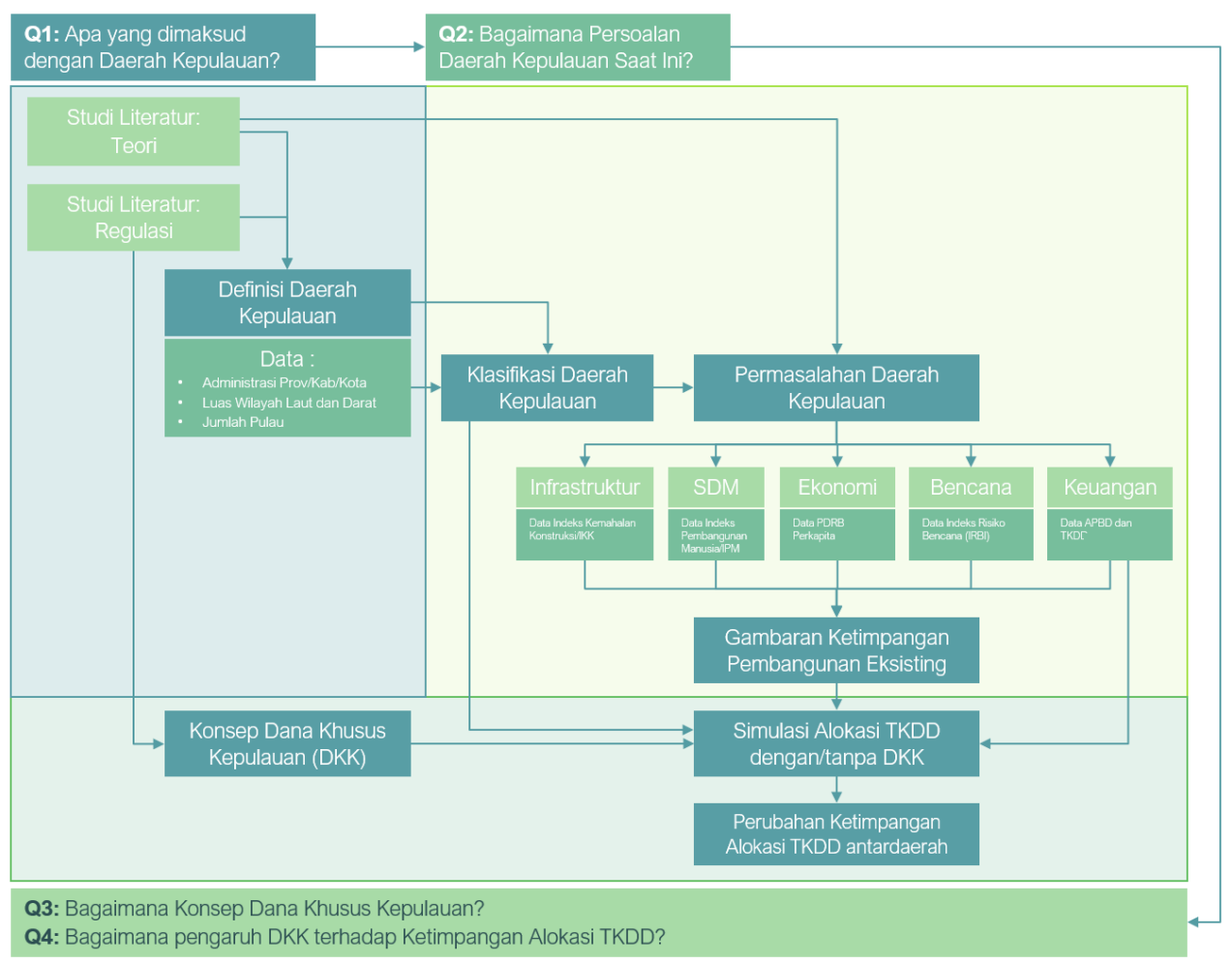

Gambar 1. Pertanyaan Penelitian dan Kerangka Analisis

\section{Hasil dan Pembahasan}

\subsection{Definisi Daerah Kepulauan}

\subsubsection{Konsep Dasar}

Landasan konstitusional mengenai daerah kepulauan terdapat pada Pasal 25A UUD Tahun 1945 amandemen keempat yang menyatakan:

"Negara Kesatuan Republik Indonesia adalah sebuah negara kepulauan yang berciri nusantara dengan wilayah yang batas-batas dan hak-haknya ditetapkan dengan undang-undang (Undang-undang Dasar Republik Indonesia Tahun 1945)”.

Dalam tingkatan Undang-undang, istilah daerah kepulauan muncul dalam Pasal 1 angka 19 Ketentuan Umum UU No. 23/2014 tentang Pemerintahan Daerah sebagai "Daerah Provinsi yang Bericiri Kepulauan dengan definisi sebagai berikut:
"Daerah Provinsi yang berciri kepulauan adalah daerah provinsi yang memiliki karakteristik secara geografis dengan wilayah lautan lebih luas dari daratan yang didalamnya terdapat pulau-pulau yang membentuk gugusan pulau sehingga menjadi satu kesatuan geografis dan sosial budaya” (Undang Undang No 23 Tahun 2014 tentang Pemerintahan Daerah).

Sehingga menurut peraturan di atas, Daerah Kepulauan hanya diakui sampai pada tingkat Provinsi sesuai dengan kewenangan atas urusan pemerintahan bidang kelautan yang otonominya diletakkan di pemerintahan daerah provinsi. Namun jika demikian, muncul persoalan terutama bagi:

1. Kabupaten/Kota yang memenuhi kriteria: memiliki wilayah lautan lebih luas dari wilayah daratan, serta memiliki pulaupulau namun tidak berada pada Daerah 
Provinsi berciri Kepulauan, ataupun sebaliknya;

2. Kabupaten/Kota yang memiliki wilayah lautan lebih kecil dari wilayah daratan dan tidak memiliki pulau-pulau, namun berada pada Daerah Provinsi berciri Kepulauan. Maka dari itu, definisi yang diusulkan dalam Naskah Akademik RUU tentang Daerah Kepulauan diperluas menjadi:

"Daerah yang memiliki karakteristik secara geografis dengan wilayah lautan lebih luas dari daratan yang didalamnya terdapat pulau-pulau yang membentuk gugusan pulau sehingga menjadi satu kesatuan geografis dan sosial budaya. (Naskah Akademik RUU tentang Daerah Kepulauan, 2019)"

Sehingga dapat mencakup semua tingkatan pemerintahan daerah baik Provinsi/Kabupaten/Kota. Meskipun berdasarkan draf terakhir Rancangan UndangUndang tentang Percepatan Pembangunan Daerah Kepulauan, definisi mengenai Daerah Kepulauan dikembalikan sesuai UU 23/2014 tentang Pemerintahan Daerah menjadi:

Daerah Kepulauan adalah provinsi kepulaun yang memiliki wilayah laut lebih luas dari wilayah darat, yang di dalamnya terdapat pulau-pulau termasuk bagian pulau yang membentuk gugusan pulau, menjadi satu kesatuan geografi, ekonomi, politik dan sosial budaya (Rancangan Undang Undang tentang Percepatan Pembangunan Daerah Kepulauan, 2020). Secara sederhana perbandingan antardefinisi mengenai Daerah Kepulauan di atas dapat dilihat pada tabel 1 .

\subsubsection{Metode Penentuan Daerah Kepulauan}

Berdasarkan definisi di atas, karena keterbatasan data, hanya tiga dari lima kriteria definisi yang dapat diukur dalam penelitian ini, yakni:

1. Status Daerah Otonom, unit analisis di tingkat provinsi, meski perlu ditinjau juga lebih dalam kondisi masing-masing kabupaten/kota

2. Luas wilayah darat dan lautan, dengan kriteria wilayah laut lebih besar dari luas wilayah darat

3. Keberadaan pulau-pulau, dengan kriteria jumlah pulau lebih dari 1

Tahapan klasifikasi daerah kepulauan berdasarkan tiga alternatif definisi menurut kerangka regulasi yang ada dapat dilihat pada gambar 2:

Tabel 1. Perbandingan Kriteria Definisi Daerah Kepulauan menurut Regulasi

\begin{tabular}{|l|c|c|c|}
\hline \multicolumn{1}{|c|}{ Kriteria Definisi } & UU 23/2014 & $\begin{array}{c}\text { NA RUU } \\
\text { Daerah } \\
\text { Kepulauan }\end{array}$ & $\begin{array}{c}\text { RUU Percepatan } \\
\text { Pembangunan Daerah } \\
\text { Kepulauan }\end{array}$ \\
\hline $\begin{array}{l}\text { Status Daerah } \\
\text { Otonom }\end{array}$ & Provinsi & $\begin{array}{c}\text { Provinsi, Kab, } \\
\text { Kota }\end{array}$ & Provinsi \\
\hline Kriteria Luas & \multicolumn{2}{|c|}{ Luas Wilayah Laut > Luas Wilayah Darat } \\
\hline $\begin{array}{l}\text { Keberadaan } \\
\text { Pulau }\end{array}$ & \multicolumn{2}{|c|}{ Terdapat Pulau-Pulau (lebih dari 1) } \\
\hline $\begin{array}{l}\text { Konfigurasi } \\
\text { Kepulauan }\end{array}$ & yang membentuk gugusan \\
Prasyarat & Membentuk kesatuan geografi ekonomi politik dan sosial budaya \\
\hline
\end{tabular}




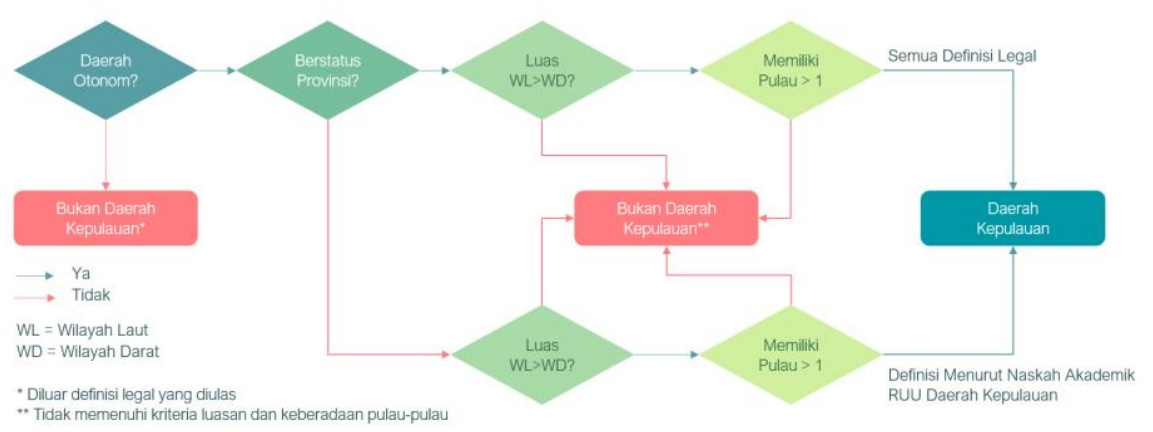

Gambar 2. Diagram Alir (Flowchart) Penentuan Daerah Kepulauan menurut Definisi berdasarkan ukuran luas wilayah darat dan

Kriteria lain seperti apakah pulau-pulau membentuk gugusan pulau atau apakah gugusan pulau yang ada membentuk kesatuan geografi, ekonomi, politik dan sosial budaya merupakan dua kriteria yang sukar dinilai oleh data-data yang tersedia. Untuk melihat apakah pulaupulau yang ada membentuk sebuah gugusan pulau membutuhkan analisis morfologi dan batimetri bahkan identifikasi kondisi fisik pulau melalui susur pantai atau survei lapangan (Kumaat, 2011). Begitupula dalam mengidentifikasi kesatuan geografi, ekonomi, politik dan sosial budaya kepulauan, belum bisa tergambarkan hanya dari angka-angka atau informasi data sekunder yang tersedia.

Untuk memperdalam analisis karakteristik geografi yang dihitung lautan, digunakan tipologi daerah menggunakan pendekatan ekosistem dan terbagi ke dalam empat kategori sebagaimana ditunjukkan pada tabel 2 .

\subsubsection{Hasil Identifikasi Daerah Kepulauan}

Daerah Kepulauan di Indonesia berdasarkan klaim politik daerah-daerah yang tergabung ke dalam Badan Kerja Sama Daerah Kepulauan (BKSDK) terdapat 8 provinsi yaitu: (1) Kepulauan Riau, (2) Kepulauan Bangka Belitung, (3) Nusa Tenggara Barat, (4) Nusa Tenggara Timur, (5) Sulawesi Utara, (6) Sulawesi Tenggara, (7) Maluku Utara, dan (8) Maluku.

Tabel 2. Tipologi Daerah menurut Kriteria Proporsi Luas Wilayah

\begin{tabular}{|l|c|c|l|}
\hline \multirow{2}{*}{\multicolumn{1}{|c|}{ Tipologi }} & \multicolumn{2}{c|}{$\begin{array}{c}\text { Kriteria Proporsi } \\
\text { Luas Wilayah }\end{array}$} & \multicolumn{1}{|}{ Deskripsi } \\
\cline { 2 - 4 } & Laut & Darat & \\
\hline Akuatik & $100 \%$ & $0 \%$ & Lautan \\
\hline $\begin{array}{l}\text { Akuatik- } \\
\text { Terestrial }\end{array}$ & $>50 \%$ & $<50 \%$ & $\begin{array}{l}\text { Daerah yang memiliki luas wilayah laut } \\
\text { lebih dibandingkan luas wilayah darat }\end{array}$ \\
\hline $\begin{array}{l}\text { Terestrial- } \\
\text { Akuatik }\end{array}$ & $<50 \%$ & $>50 \%$ & $\begin{array}{l}\text { Daerah yang memiliki luas wilayah darat } \\
\text { lebih luas dibandingkan luas wilayah laut }\end{array}$ \\
\hline Terestrial & $0 \%$ & $100 \%$ & $\begin{array}{l}\text { Daerah Daratan yang tidak memiliki } \\
\text { pesisir dan wilayah laut (landlocked) }\end{array}$ \\
\hline
\end{tabular}

Sumber: Dimodifikasi dari (Stefanus, 2011) 


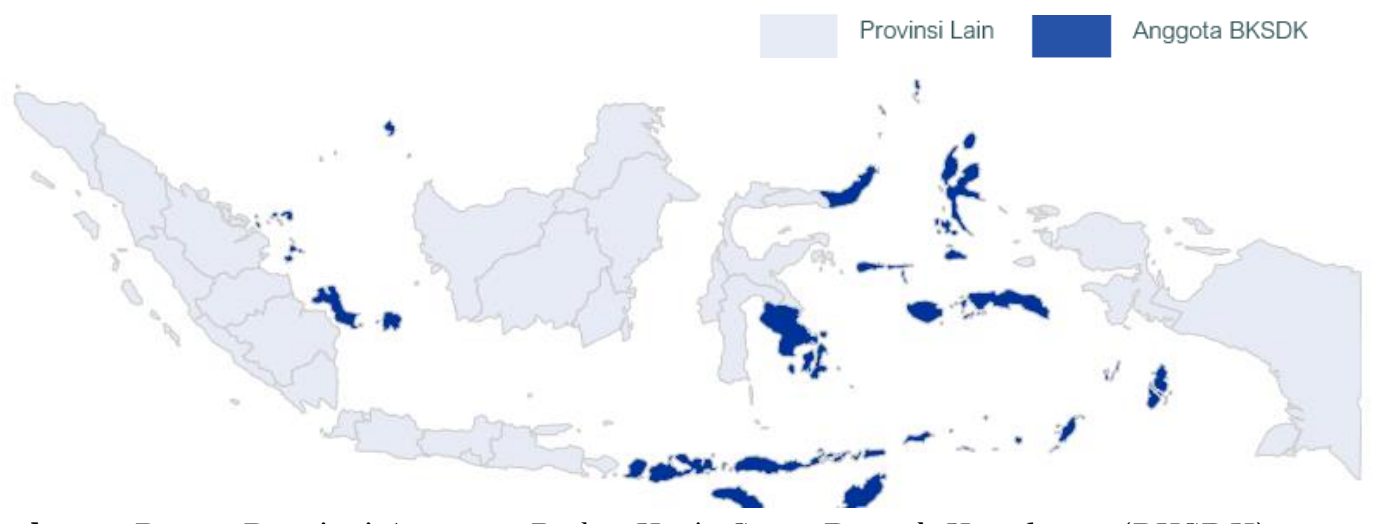

Gambar 3. Peta 8 Provinsi Anggota Badan Kerja Sama Daerah Kepulauan (BKSDK)

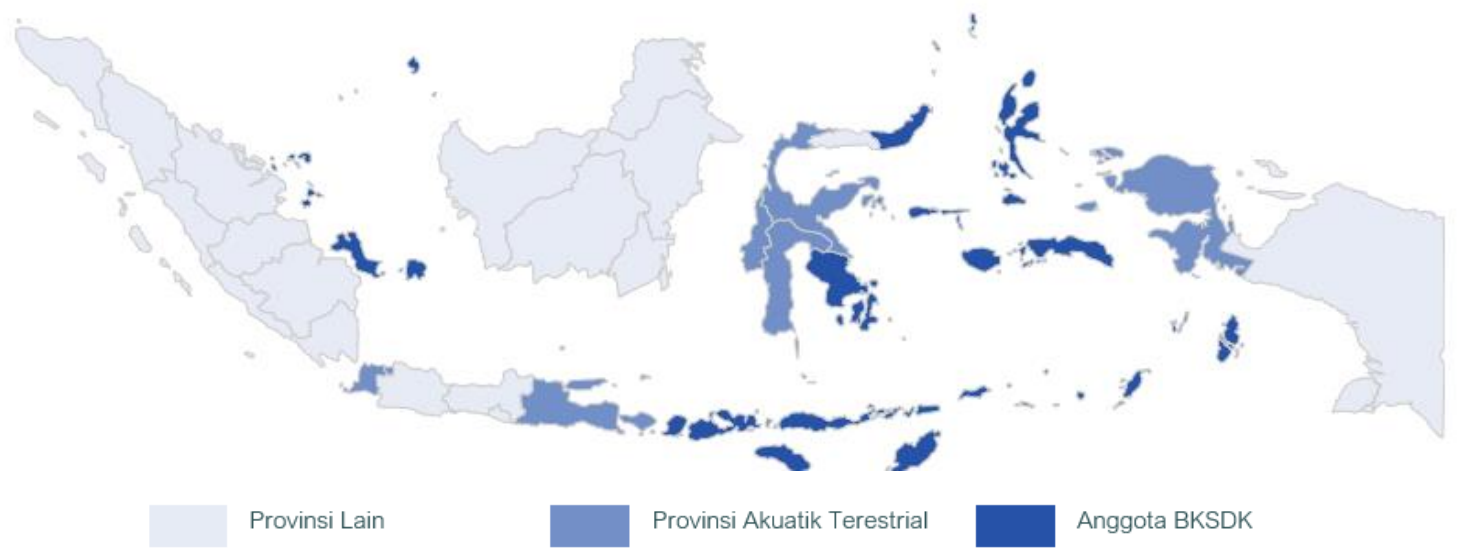

Gambar 4. Peta 16 Provinsi yang memiliki karakteristik Akuatik-Terestrial (termasuk BKSDK)

Jika dilihat berdasarkan proporsi luas wilayah laut terhadap total luas wilayah terdapat 16 Provinsi yang memiliki tipologi Akuatik-Terestrial atau dengan luas wilayah laut lebih dari 50\% (setara $47.06 \%$ dari jumlah provinsi di Indonesia). Selain 8 Provinsi anggota BKSDK, terdapat 8 Provinsi lain yaitu: (1) DKI Jakarta, (2) Sulawesi Selatan, (3) Provinsi Bali, (4) Provinsi Sulawesi Barat, (5) Provinsi
Sulawesi Tengah, (6) Provinsi Banten, (7) Provinsi Jawa Timur, dan (8) Provinsi Papua Barat.

Kriteria yang lain ialah keberadaan pulaupulau yang lebih dari satu dan membentuk gugusan pulau. Karena hanya jumlah saja yang bisa diidentifikasi maka keberadaan gugusan pulau belum dapat diamati dalam penelitian ini. 


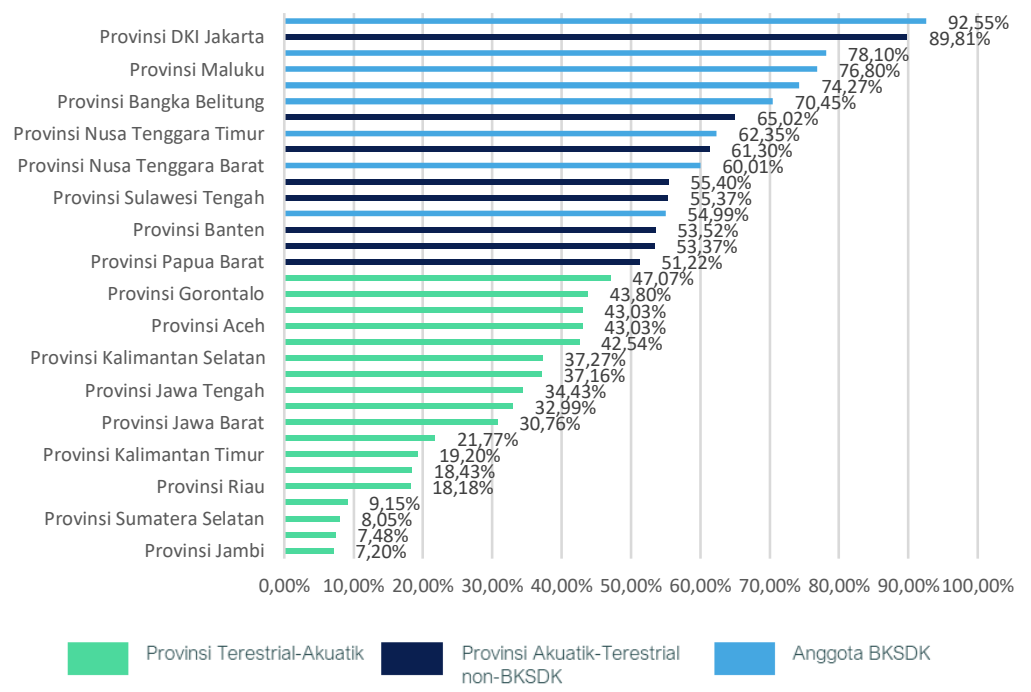

Gambar 5. Daerah Provinsi menurut Tipologi Proporsi Luas Wilayah Sumber data: (DJPK Kemenkeu, 2018)

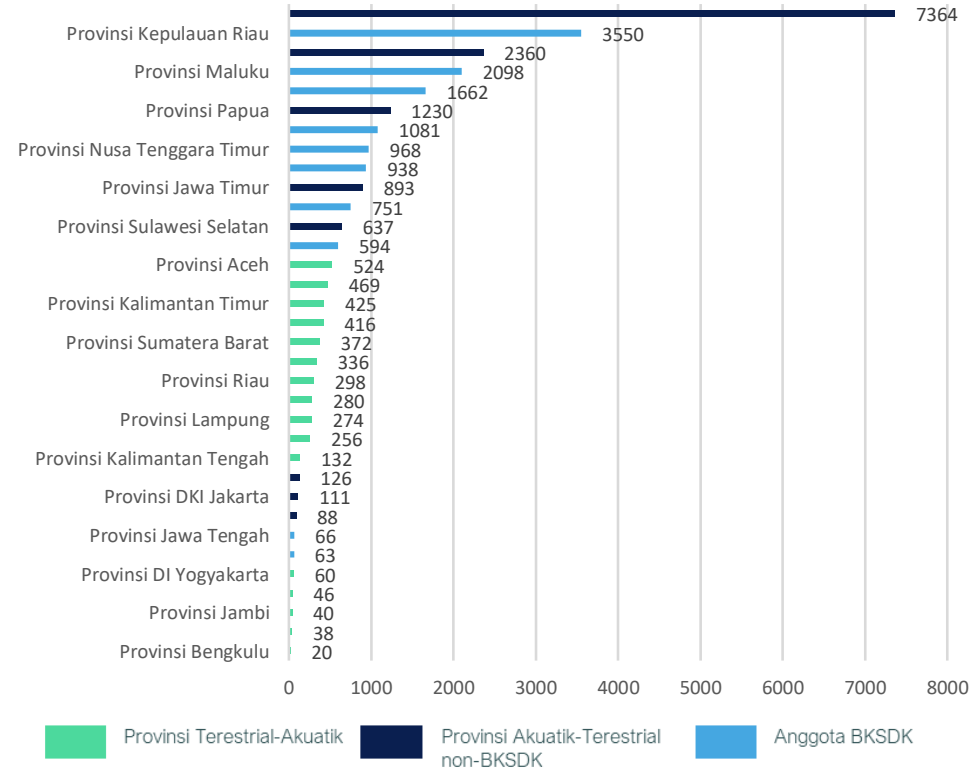

Gambar 6. Daerah Provinsi menurut Jumlah Pulau Sumber data: (Nomor.net, 2020)

Berdasarkan jumlahnya, tidak semua Provinsi yang memiliki banyak pulau tergabung ke dalam BKSDK, contohnya: Papua Barat, sebagai provinsi dengan jumlah pulau terbanyak (7364 pulau) dan Sulawesi Tengah menjadi provinsi dengan jumlah pulau ketiga terbanyak (2360 pulau).

Bahkan terdapat provinsi dengan karakteristik terrestrial-akuatik, namun memiliki banyak pulau contohnya Aceh (524 pulau) yang jumlahnya jauh di atas provinsi 
dengan karakteristik akuatik terrestrial (Banten - 126 pulau, Jakarta - 111 pulau, dan Sulawesi Barat - 88 pulau). Sehingga apabila dilihat dengan cara provinsi yang memiliki lebih dari satu pulau, maka 100\% Provinsi di Indonesia memenuhi kriteria tersebut. (Provinsi Bengkulu sebagai provinsi dengan jumlah pulau yang paling sedikit: 20 pulau).

Apabila dilihat dari keberadaan Kab/Kota bertipologi Akuatik-Terestrial dan memiliki pulau sebagai Kab/Kota berciri Kepulauan, maka dari 33 provinsi yang diamati (DKI Jakarta dikecualikan karena tidak memiliki daerah otonom di bawahnya) hanya 10 Daerah yang tidak memiliki Kab/Kota berciri Kepulauan, yaitu: (1) Provinsi Sumatera Selatan, (2) Sulawesi Barat, (3) Riau, (4) Kalimantan Timur, (5) Kalimantan Tengah, (6) Kalimantan Selatan, (7) Jawa Barat, (8) Jambi, (9) Gorontalo, (10) DI Yogyakarta. Namun karena Sulawesi Barat secara provinsi memenuhi tipologi akuatik-terestrial, sehingga terdapat total 25 Provinsi (setara 73.53\%) memenuhi ciri daerah kepulauan.

Berdasarkan hasil analisis di atas dapat diperoleh tiga jenis daerah kepulauan yang ditunjukkan pada tabel 3:

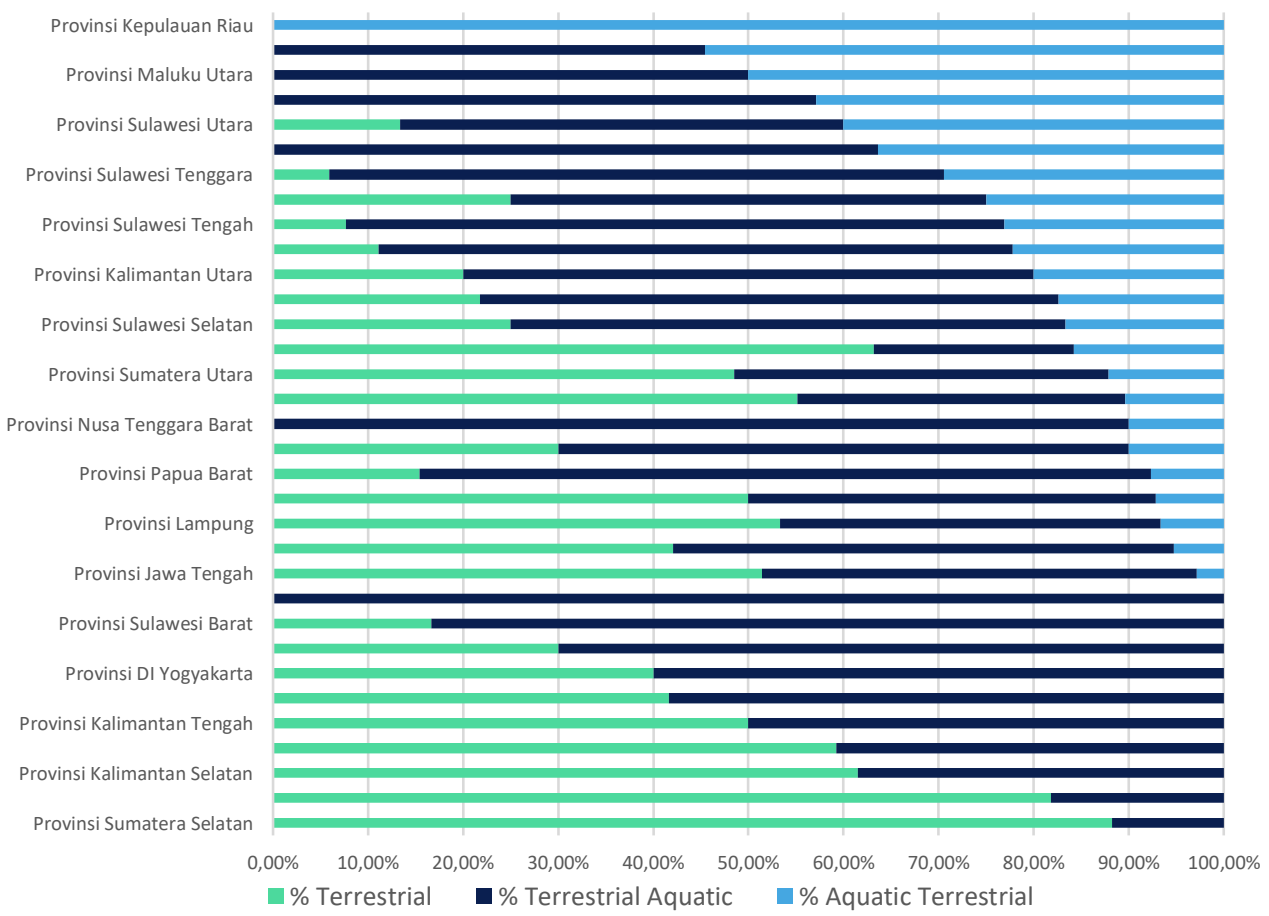

Gambar 7. Proporsi Kab/Kota berdasarkan Tipologi menurut Provinsi Sumber data: (DJPK Kemenkeu, 2018) 


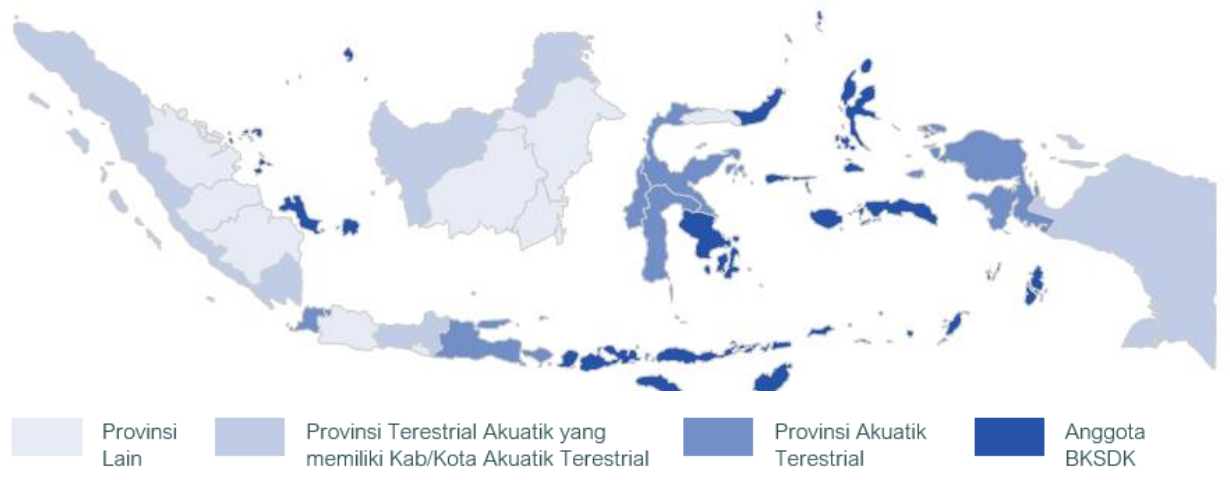

Gambar 8. Peta hasil Pertampalan (overlay) Provinsi Berciri Kepulauan berdasarkan kategori definisi

Tabel 3. Tipologi Daerah Kepulauan di Indonesia

\begin{tabular}{|c|c|c|c|}
\hline & \multicolumn{3}{|c|}{ Daerah Kepulauan } \\
\hline & Tipe I & Tipe II & Tipe III \\
\hline Kriteria & $\begin{array}{c}\text { Klaim Anggota } \\
\text { BKSDK }\end{array}$ & $\begin{array}{c}\text { Provinsi dengan Luas } \\
\text { Wilayah Laut lebih } \\
\text { dari } 50 \%\end{array}$ & $\begin{array}{c}\text { Memiliki Kab/Kota yang } \\
\text { luas wilayah lautnya lebih } \\
\text { dari } 50 \%\end{array}$ \\
\hline Jumlah & 8 Provinsi & 16 Provinsi & 25 Provinsi \\
\hline Provinsi & $\begin{array}{l}\text { Kepulauan Riau, } \\
\text { Kepulauan Bangka } \\
\text { Belitung, NTB, NTT, } \\
\text { Sulawesi Utara, } \\
\text { Sulawesi Tenggara, } \\
\text { Maluku, Maluku } \\
\text { Utara }\end{array}$ & $\begin{array}{l}\text { Tipe I + } \\
\text { Banten, Jawa Timur, } \\
\text { Bali, Sulawesi Barat, } \\
\text { Sulawesi Selatan, } \\
\text { Sulawesi Tengah, } \\
\text { Papua Barat }\end{array}$ & $\begin{array}{l}\text { Tipe I + Tipe II + } \\
\text { Aceh, Sumatera Utara, } \\
\text { Sumatera Barat, } \\
\text { Bengkulu, Lampung, Jawa } \\
\text { Tengah, Kalimantan } \\
\text { Barat, Kalimantan Utara, } \\
\text { Papua }\end{array}$ \\
\hline
\end{tabular}

3.2. Tantangan dan Permasalahan Daerah Kepulauan

\subsubsection{Karakteristik Daerah Kepulauan}

Menurut Santoso (2009) daerah kepulauan memiliki realitas yang berbeda dari daerah non kepulauan, diantaranya ialah:

1. secara sosiologis provinsi kepulauan memiliki perbedaan yang spesifik dengan provinsi lain sehingga model pembangunannya harus berbeda dengan model yang umum;

2. manajemen administrasi pemerintahan haruslah berbasis kepulauan;
3. pelayanan masyarakat harus diarahkan ke pulau-pulau karena masyarakat provinsi kepulauan hidup pada pulau-pulau terisolir;

4. rata-rata masyarakat pada daerah kepulauan terlambat dalam pembangunan infrastruktur

5. pulau kecil terluar membutuhkan pendekatan prosperity dan security secara bersamaan

Badan Kerja Sama Daerah Kepulauan (BKSDK) telah menegaskan bahwa karakter pembeda antara provinsi kepulauan dengan provinsi lain ialah (Stefanus, 2011): 
1. Geografis: Luas wilayah laut yang lebih luas dari wilayah daratan

2. Demografis: Penduduk wilayah kepulauan biasanya bersifat relative sedikit dan persebarannya tidak merata

3. Sosial Budaya: Komunitas-komunitas di wilayah kepulauan tersegregasi dalam permukiman menurut teritorial pulaupulau, sehingga berimplikasi pada kuatnya rasa keterikatan terhadap pulau. Selain itu pola hidup pada pulau-pulau kecil selaras dengan alam sehingga cenderung lamban menerima perubahan

4. Ketersediaan SDA: memiliki sumber daya alam yang relatif beragam

5. Sistem Kehidupan: ditentukan oleh tingkat isolasi geografis dengan keunikan habitat (endemis) dan keanekaragaman hayati (biodiversitas)

6. Sosial Ekonomi: aktivitas ekonomi, jenis dan derajat dinamika ekonomi umumnya terbatas dan berskala kecil serta belum didukung oleh jaringan distribusi dan pemasaran secara memadai

7. Lingkungan dan Kebencanaan: memiliki kerentanan tinggi terhadap perubahan (entrophy), rawan bencana alam (gelombang permukaan laut, kenaikan muka air laut, tsunami, dsb.)

8. Biogeografi: potensi keanekaragaman hayati darat, pesisir dan perairan sekitar pulau-pulau
9. Pertahanan dan Keamanan: hampir semua provinsi kepulauan berada pada wilayah kawasan perbatasan negara (kecuali Bangka Belitung dan Sulawesi Tenggara jika dalam konteks BKSDK)

Berdasarkan uraian tantangan, realitas, dan karakteristik daerah kepulauan di atas, masalah-masalah pokok yang dihadapi ialah (1) akses terhadap pelayanan pemerintahan dan pelayanan dasar yang memadai baik dari ketersediaan infrastruktur maupun aksesibilitas infrastruktur; (2) rendahnya kualitas sumber daya manusia; (3) terbatasnya kemampuan keuangan daerah dan ketergantungan fiskal yang sangat tinggi pada pemerintah; yang menyebabkan (4) disparitas layaan, ekonomi dan kesejahteraan antarwilayah; ditambah (5) tingginya ancaman bencana termasuk yang disebabkan oleh perubahan iklim.

\subsubsection{Permasalahan Daerah Kepulauan}

Untuk menguji persoalan di atas, akan dianalisa persoalan yang diduga spesifik kepulauan dan menjadi latar belakang perlunya alokasi Dana Khusus Kepulauan (DKK), menggunakan definisi daerah kepulauan pada Naskah Akademik RUU Daerah Kepulauan yaitu Luas Wilayah > 50\% Laut, dan memiliki pulau-pulau, dengan memasukkan seluruh variabel administrasi untuk mendetailkan granulasi data (tidak hanya provinsi), yang akan dibahas secara terpisah menurut permasalahan

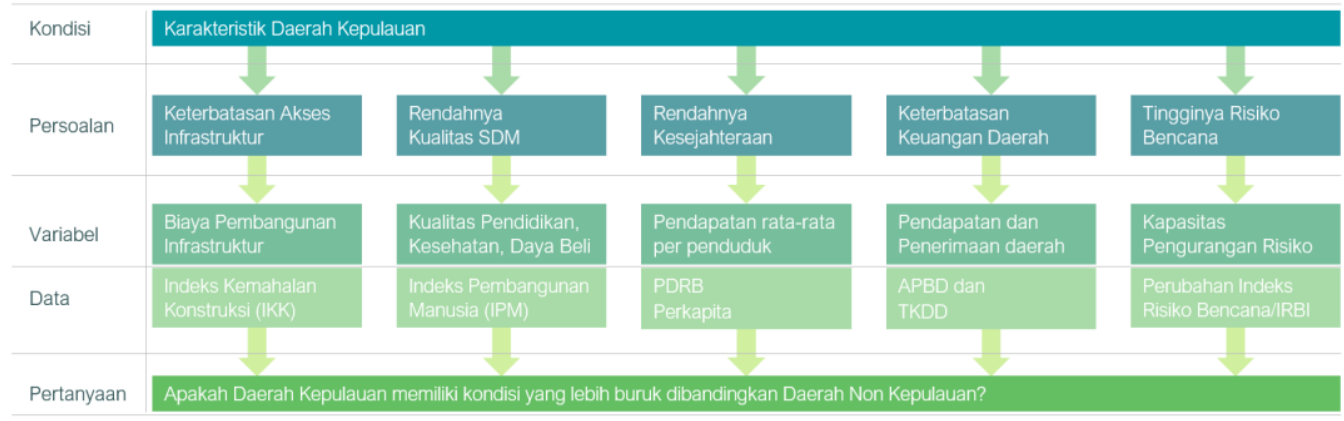

Gambar 9. Kerangka Analisis Permasalahan Daerah Kepulauan 
pokok sesuai dengan kerangka analisis pada Gambar 9.

\subsubsection{Kemahalan Konstruksi Daerah Kepulauan}

Salah satu urgensi Dana Khusus Kepulauan (DKK) ialah karena kemahalan biaya konstruksi untuk membangun di daerah kepulauan. Sehingga menyebabkan keterbatasaan ketersediaan dan akses terhadap infrastruktur berkualitas.

Berdasarkan hasil analisis IKK antarwilayah pulau, daerah kepulauan dan nonkepulauan. Temuan yang diperoleh ialah IKK daerah kepulauan relatif lebih tinggi dibandingkan daerah non kepulauan, kecuali:

1. Daerah kota kepulauan (berkarakteristik akuatik terestrial) di wilayah Bali Nusa Tenggara memiliki IKK lebih rendah dibandingkan kota pedalaman (berkarakteristik terestrial akuatik/terestrial)
2. Wilayah Maluku Papua (untuk semua jenis daerah: Provinsi, Kabupaten, Kota) IKK daerah kepulauan lebih rendah dibandingkan IKK daerah pedalaman

Temuan ini menjelaskan bahwa persoalan utamanya bukan terletak dari Kepulauan atau Bukan Kepulauan, tetapi tersedia atau tidaknya akses untuk distribusi logistik dan bahan konstruksi untuk melaksanakan pembangunan. Terbukti di daerah Maluku Papua dan Kota-kota di Bali Nusa Tenggara, justru Daerah Kepulauan lah yang memiliki rata-rata IKK yang relatif lebih rendah dibanding Daerah Non Kepulauan, karena yang Non Kepulauan lebih terisolir dan sulit diakses dibandingkan Daerah Kepulauan. Sehingga IKK ini isunya lebih kepada ketimpangan Timur-Barat dibandingkan ketimpangan Kepulauan dan Non Kepulauan.

Stimulus Fiskal dalam bentuk Dana Khusus Kepulauan, bagi Daerah Kepulauan di Region yang persoalannya lebih banyak di keterisolasian wilayah darat, akan semakin memperlebar kesenjangan pembangunan antara pesisir/kepulauan dan wilayah pedalaman.

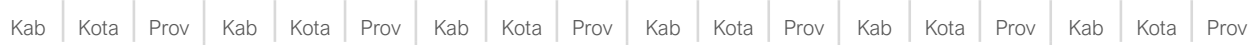

Gambar 10. Perbandingan Indeks Kemahalan Konstruksi

Sumber data: (DJPK Kemenkeu, 2018) 


\subsubsection{Sumber Daya Manusia Daerah Kepulauan}

Kualitas Sumber Daya Manusia Daerah Kepulauan akan dilihat melalui perbandingan IPM Daerah Kepulauan dan Non Kepulauan. Berdasarkan data pada gambar 11, Rata-rata Provinsi dan Kota di Sumatera, Provinsi di Jawa, Kota di Bali - Nusa Tenggara, Kota dan Provinsi di Sulawesi, serta Kabupaten dan Provinsi di Maluku-Papua, yang memiliki ciri Kepulauan justru memiliki rata-rata IPM lebih baik dibandingkan Daerah Non Kepulauan, dan Daerah Kota memiliki rata-rata IPM paling tinggi di semua region. Sehingga IPM juga isunya lebih kepada ketimpangan Kota-Desa dibandingkan ketimpangan Kepulauan dan Non Kepulauan.

\subsubsection{Ekonomi dan Kesejahteraan Daerah Kepulauan}

Kinerja Perekonomian Wilayah dan Kesejahteraan masyarakat daerah kepulauan dilihat melalui PDRB perkapita. Hasilnya, dapat dilihat di seluruh wilayah pulau, kota memiliki PDRB perkapita paling tinggi, dan kecuali wilayah pulau Maluku Papua daerah kota yang berciri kepulauan lebih tinggi dibandingkan kota non kepulauan. Di wilayah Sumatera, Kab/Kota/Provinsi kepulauan lebih tinggi dibanding non kepulauan; Kota dan Provinsi Kepulauan di Jawa lebih tinggi dibanding non kepulauan; Kabupaten di Maluku-Papua, Kota dan Provinsi di Sulawesi, yang berciri kepulauan memiliki PDRB perkapita lebih tinggi dibanding NonKepulauan.

Berdasarkan hasil pada gambar 12, dapat dilihat bahwa isu PDRB perkapita bukan ketimpangan Kepulauan dan Non Kepulauan, namun lebih pada ketimpangan kota-non kota, dan Jawa-non Jawa. Bahkan beberapa kota yang berada di daerah dengan luas laut lebih dari 50\% memiliki PDRB perkapita lebih baik dibandingkan kota-kota pedalaman kecuali di Wilayah Maluku dan Papua.

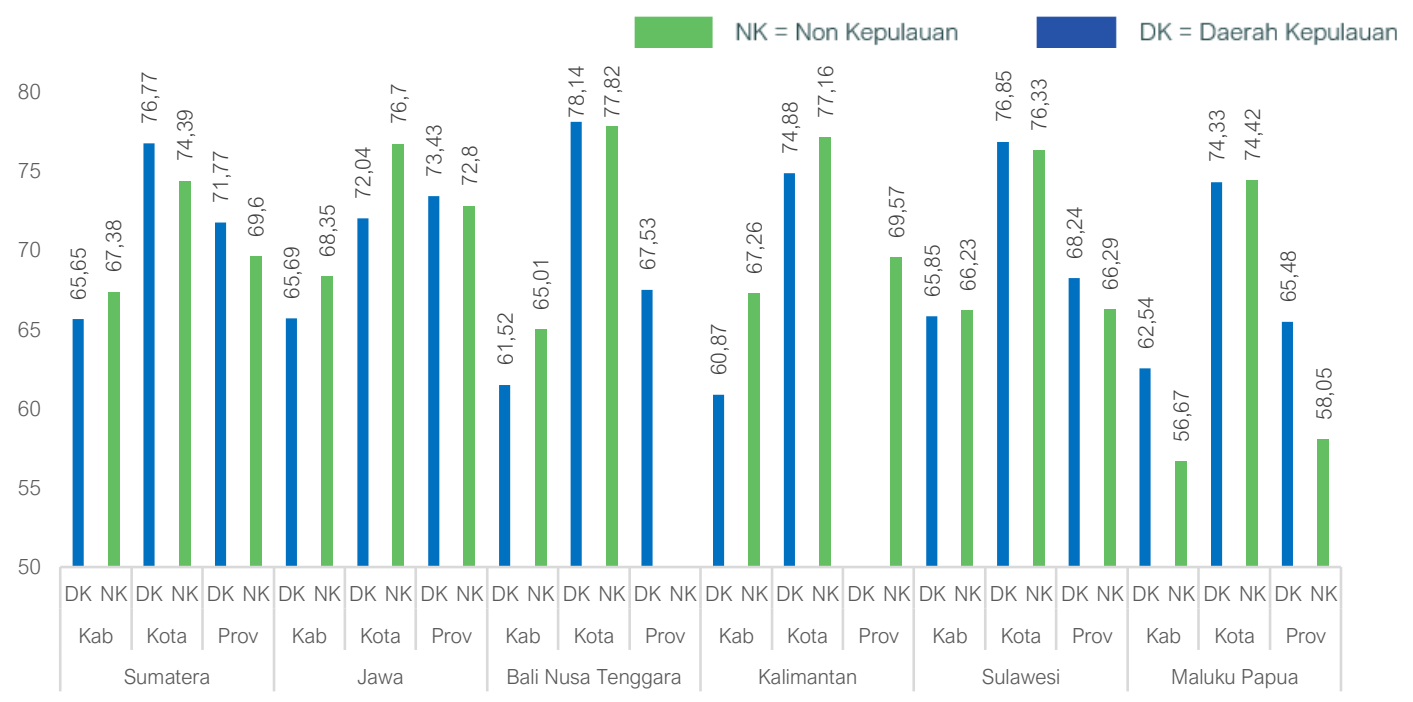

Gambar 11. Perbandingan Indeks Pembangunan Manusia Sumber data: (DJPK Kemenkeu, 2018) 


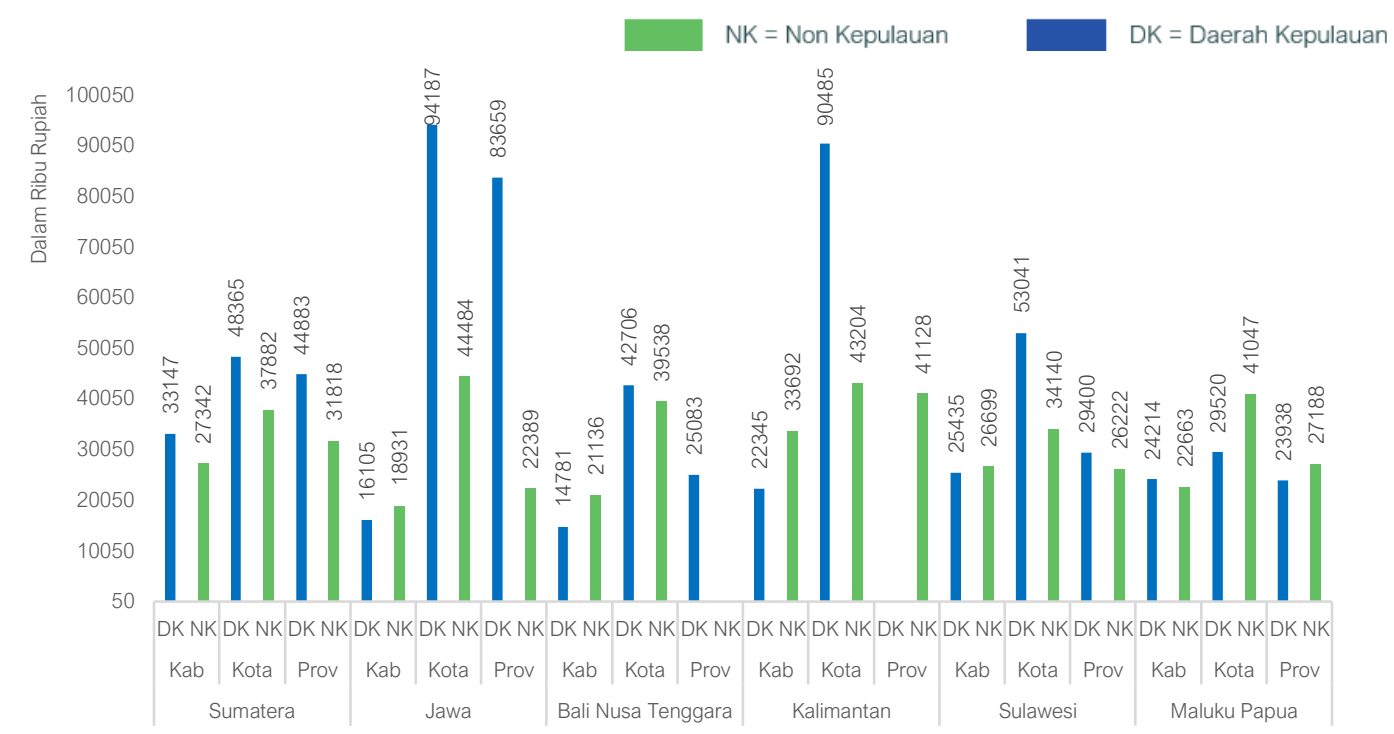

Gambar 12. Perbandingan PDRB perkapita

Sumber data: (DJPK Kemenkeu, 2018)

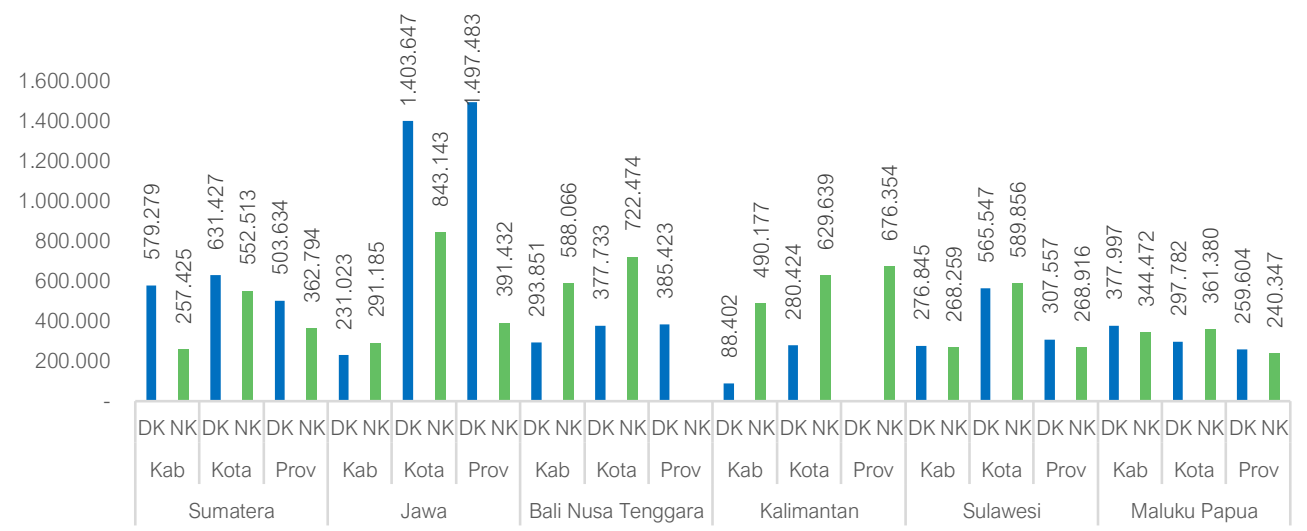

Gambar 13. Perbandingan PAD perkapita

Sumber data: (DJPK Kemenkeu, 2018)

\subsubsection{Kemampuan Keuangan Daerah Kepulauan}

Untuk mengukur Keuangan Daerah Kepulauan akan dilihat dari Pendapatan Asli Daerah (PAD) perkapita dan PAD per $\mathrm{Km}^{2}$. Data yang digunakan ialah Anggaran Pendapatan dan Belanja Daerah tahun fiskal 2018 (APBD 2018 - Anggaran).

Dari data rata-rata PAD per Kapita yang ditunjukkan pada Gambar 13 dapat dilihat bahwa konsentrasi bangkitan PAD per kapita masih dipimpin Jawa dan Sumatera. Bahkan di Sumatera, Daerah Kepulauan baik Kabupaten, Kota dan Provinsi; Kota dan Provinsi Kepulauan di Jawa; Kabupaten dan Provinsi di Sulawesi dan Maluku-Papua, memiliki Bangkitan PAD lebih tinggi dibandingkan Non Kepulauan.

Rata-rata PAD per-Km² (berdasarkan luas wilayah) memang terkonsentrasi di kotakota (di semua wilayah). Hal ini dapat dipahami karena kebijakan mengenai Pajak Daerah dan Retribusi Daerah (PDRD) memang bias perkotaan (urban bias). Sedangkan Daerah 
Kabupaten baik kepulauan atau bukan, berdasarkan tipologi luas wilayah: terestrial, kekurangan basis PDRD yang menjadi sumber terestrial-akuatik dan akuatik-terestrial. utama PAD.

\subsubsection{Ketangguhan Daerah Kepulauan}

Untuk memotret ketangguhan daerah kepulauan didalami risiko bencana di 98 kota Berdasarkan hasil analisis yang dapat dilihat pada Gambar 15 dapat dilihat secara historis tahun 2015-2019 bahwa daerah kota terestrialakuatik memiliki risiko bencana yang relatif lebih tinggi, dan daerah kota berkarakter terestrial cenderung paling rendah risikonya.

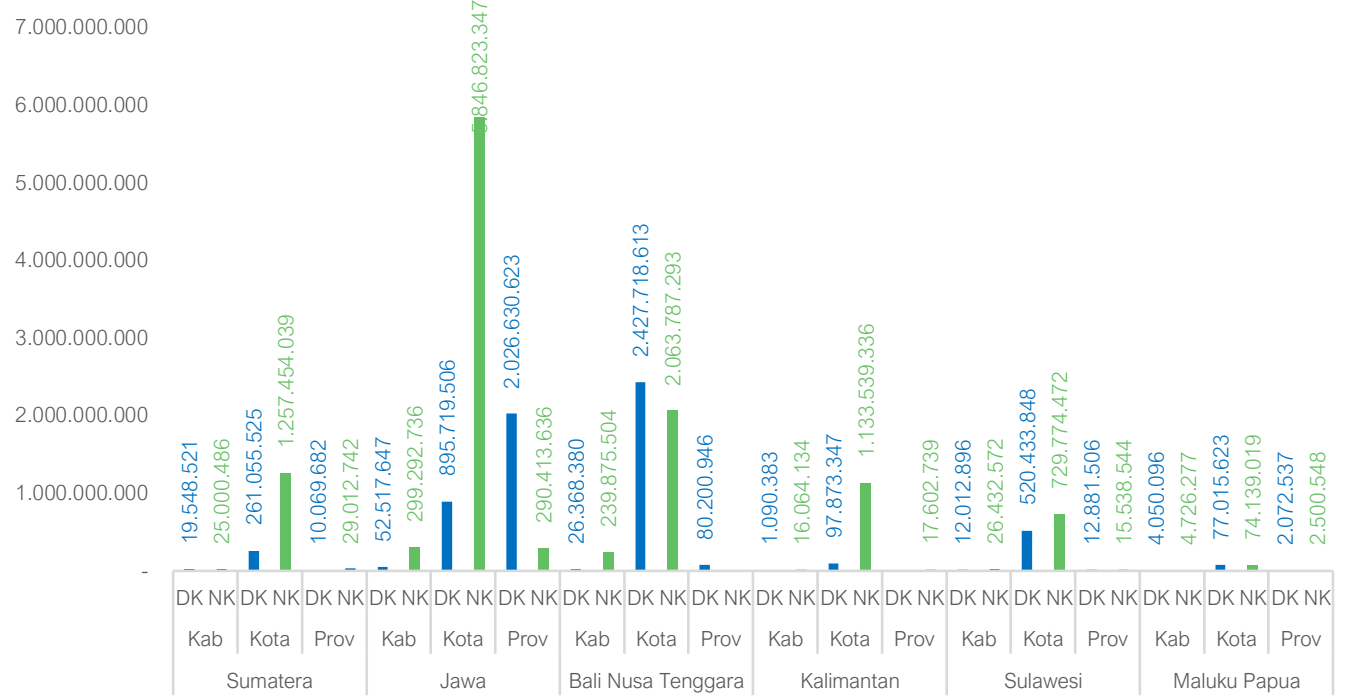

Gambar 14. Perbandingan PAD perkm²

Sumber data: (DJPK Kemenkeu, 2018)

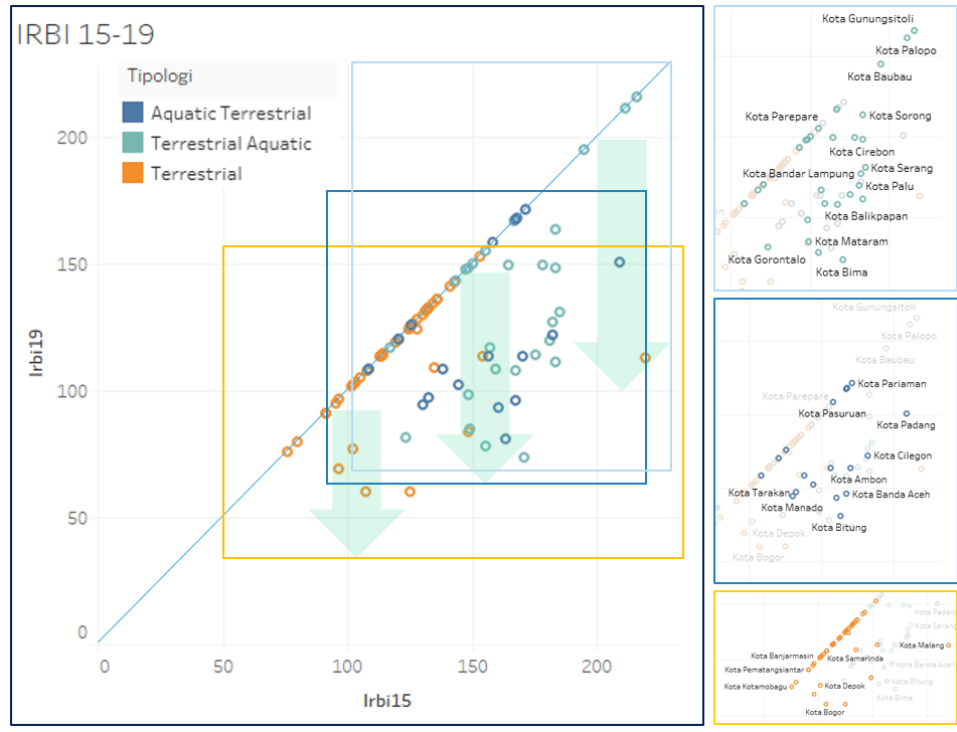

Gambar 15. Scatterplot Risiko IRBI 2015-2019

Sumber data: (BNPB, 2016; BNPB, 2019) 


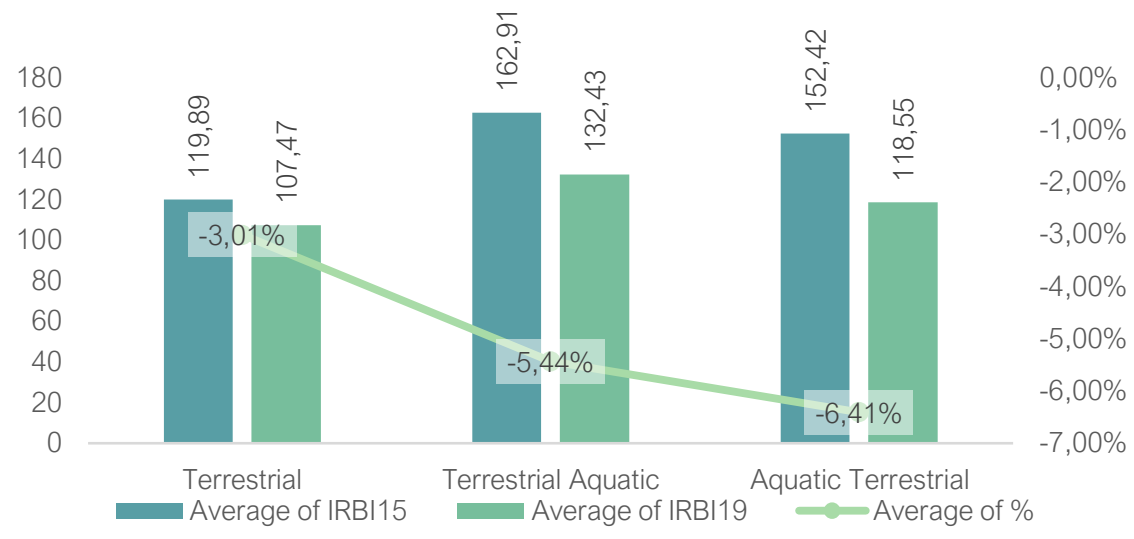

Gambar 16. Perubahan Risiko IRBI 2015-2019

Sumber data: (BNPB, 2016; BNPB, 2019)

Hal ini mengkonfirmasi bahwa daerah yang memiliki wilayah laut memiliki risiko bencana lebih tinggi dibandingkan kota berkarakter daratan (terestrial). Meskipun untuk konteks kota ditemukan bahwa kota dengan karakteristik akuatik terestrial ternyata memiliki rata-rata risiko yang relatif lebih rendah dibandingkan kota dengan karakteristik terestrial akuatik.

Berdasarkan upaya pengurangan risiko bencana bisa dilihat pada Gambar 16 bahwa dalam kurun waktu 2015-2019 kota-kota akuatik-terestrial ialah daerah yang paling progresif dalam mengurangi risiko bencana. Dari semula rata-rata 152.42 di tahun 2015 menjadi 118.55 di tahun 2019 atau pengurangan sebesar $-6.41 \%$. Fakta ini menunjukan bahwa tanpa Dana Khusus Kepulauan selama 20152019, kota-kota kepulauan telah bisa berhasil meningkatkan kapasitas dalam menghadapi risiko bencana termasuk yang diakibatkan oleh Perubahan Iklim.

\subsection{Konsep Dana Khusus Kepulauan}

Secara konsep, menurut Naskah Akademik RUU tentang Daerah Kepulauan dijelaskan bahwa Dana Khusus Kepulauan diatur dalam beberapa bagian:
- Pada Bab I Ketentuan Umum angka 19, Dana Khusus Kepulauan (DKK) didefinisikan sebagai:

"Dana Khusus Kepulauan yang selanjutnya disingkat DKK adalah dana yang bersumber dari Anggaran Pendapatan dan Belanja Negara yang dialokasikan untuk mendukung pembangunan Daerah Kepulauan. (Naskah Akademik RUU tentang Daerah Kepulauan, 2019)"

- Pada Pasal 30 disebutkan lebih rinci yaitu: “(1) Pemerintah mengalokasikan DKK paling sedikit 5\% (lima persen) dari dan di luar pagu dana transfer umum; (2) DKK diprioritaskan untuk membantu mendanai pengembangan sektor ekonomi kelautan prioritas dan pembangunan sarana dan prasarana laut, darat, dan udara sesuai karakteristik Daerah Kepulauan; (3) DKK diperuntukan bagi dan dikelola Pemda Kepulauan yang pengalokasian dan penyalurannya melalui mekanisme transfer ke daerah (Naskah Akademik RUU tentang Daerah Kepulauan, 2019)”

Dalam draf Rancangan Undang Undang (RUU) Republik Indonesia tentang Percepatan Pembangunan Daerah Kepulauan tidak 
ditemukan terminologi khusus mengenai Dana Khusus Kepulauan (DKK). Dana semacam ini disinggung pada Pasal 29 dan Pasal 32:

- Pasal 29 disebutkan bahwa penerimaan daerah kepulauan dalam rangka percepatan pembangunan sebagai salah satu sumber-sumber penerimaan daerah kepulauan:

"Sumber-sumber penerimaan Daerah Kepulauan meliputi: a. pendapatan asli daerah kepulauan; b. dana perimbangan; c. penerimaan daerah kepulauan dalam rangka percepatan pembangunan; d. pinjaman daerah; dan e. lain-lain penerimaan yang sah. (Rancangan Undang Undang tentang Percepatan Pembangunan Daerah Kepulauan, 2020)”

- Pasal 32 disebutkan lebih rinci sebagai berikut:
“(1) Penerimaan Daerah Kepulauan untuk percepatan pembangunan diperoleh dari penerimaan khusus yang besarnya setara dengan $1 \%$ (satu persen) dari plafon dana alokasi umum yang diutamakan untuk pembiayaan pendiidkan, kesehatan dan pembangunan infrastruktur;

Penerimaan Daerah Kepulauan untuk percepatan pembangunan berlaku paling lama 25 tahun; (3) Pemerintah melakukan evaluasi setiap tahun; (4) Ketentuan lebih lanjut diatur PP. (Rancangan Undang Undang tentang Percepatan Pembangunan Daerah Kepulauan, 2020)” Sehingga terdapat dua konsep Dana Khusus Kepulauan yang diajukan dalam Naskah Akademik RUU Daerah Kepulauan dan Draf RUU Percepatan Pembangunan Daerah Kepulauan dengan penjabaran sebagai berikut:

Tabel 4. Perbedaan Konsep Dana Khusus Kepulauan

\begin{tabular}{|c|c|c|}
\hline $\begin{array}{l}\text { Kriteria } \\
\text { Pembeda }\end{array}$ & $\begin{array}{c}\text { Naskah Akademik } \\
\text { RUU Daerah Kepulauan }\end{array}$ & $\begin{array}{c}\text { Draf RUU Percepatan Pembangunan } \\
\text { Daerah Kepulauan }\end{array}$ \\
\hline Istilah & Dana Khusus Kepulauan (DKK) & $\begin{array}{c}\text { Penerimaan Daerah Kepulauan untuk } \\
\text { Percepatan Pembangunan }\end{array}$ \\
\hline Besaran & $5 \% \mathrm{DTU}$ & $1 \% \mathrm{DAU}$ \\
\hline Masa Berlaku & Tidak diatur & Paling lama 25 tahun \\
\hline $\begin{array}{l}\text { Peruntukan/ } \\
\text { Penggunaan }\end{array}$ & $\begin{array}{l}\text { Pengembangan sektor ekonomi } \\
\text { kelautan prioritas dan pembangunan } \\
\text { sarana dan prasarana laut, darat, dan } \\
\text { udara sesuai karakteristik Daerah } \\
\text { Kepulauan }\end{array}$ & $\begin{array}{l}\text { Diutamakan untuk pembiayaan } \\
\text { pendidikan, kesehatan dan } \\
\text { pembangunan infrastruktur }\end{array}$ \\
\hline $\begin{array}{l}\text { Mekanisme } \\
\text { Alokasi }\end{array}$ & Transfer ke Daerah & Tidak diatur \\
\hline $\begin{array}{l}\text { Pemantauan } \\
\text { Evaluasi dan } \\
\text { Pengaturan } \\
\text { lebih lanjut }\end{array}$ & Tidak diatur & $\begin{array}{c}\text { Dilakukan pemantauan dan evaluasi } \\
\text { oleh pemerintah setiap tahun, diatur } \\
\text { lebih lajut di } \\
\text { Peraturan Pemerintah }\end{array}$ \\
\hline
\end{tabular}


3.4. Evaluasi Ex Ante terkait Dampak Kebijakan Dana Khusus Kepulauan terhadap Ketimpangan Alokasi Transfer ke Daerah

Karena keterbatasan informasi mengenai mekanisme alokasi penerimaan daerah kepulauan untuk percepatan pembangunan, maka yang akan dievaluasi ialah Dana Khusus Kepulauan (DKK) menurut versi Naskah Akademik RUU Daerah Kepulauan, melalui mekanisme alokasi Transfer ke Daerah.

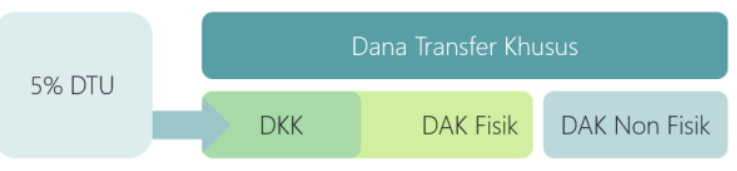

Gambar 17. Ilustrasi kedudukan DKK dalam struktur DTK

Memperhatikan ketentuan peruntukan atau penggunaan DKK yaitu untuk Pengembangan sektor ekonomi kelautan prioritas dan pembangunan sarana dan prasarana laut, darat, dan udara sesuai karakteristik Daerah Kepulauan, maka dalam hal ini diasumsikan bahwa DKK dialokasikan sebagai dana on-top sebesar 5\% DTU Nasional (terdiri atas DAU dan DBH) di dalam kategori Dana Transfer Khusus (menjadi tambahan alokasi bagi DAK Fisik).

Dengan menggunakan data alokasi Transfer Ke Daerah dan Dana Desa (TKDD) tahun anggaran 2018 diperoleh gambaran skenario dampak kebijakan Dana Khusus Kepulauan yang ditunjukkan pada Gambar 18:

Skenario I: tanpa intervensi DKK, ketimpangan alokasi maksimal dan minimal pada dana Transfer ke Daerah kategori DAK Fisik sebesar 4.37 T. Skenario II: apabila DKK diberikan kepada 8 Provinsi BKSDK secara proporsional menurut proporsi wilayah laut, ketimpangan alokasi meningkat sebesar 25.12\% menjadi 5.14 T. Skenario III: apabila DKK diberikan pada seluruh daerah provinsi yang berciri kepulauan menurut proporsi wilayah laut, maka ketimpangan alokasi akan meningkat $40.65 \%$ hingga $6.18 \mathrm{~T}$.

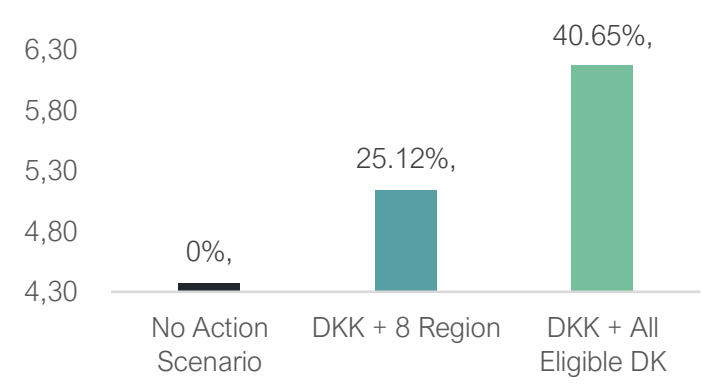

Gambar 18. Perubahan skenario ketimpangan alokasi antardaerah

\section{Temuan dan Rekomendasi}

\subsection{Temuan}

Berdasarkan definisi, terjadi ekslusi kabupaten/kota yang memenuhi parameter daerah kepulauan karena adanya batasan kewenangan atas urusan pemerintahan pilihan bidang kelautan yang merupakan urusan konkuren kewenangan pemerintahan provinsi. Hal ini perlu menjadi perhatian karena berpotensi konflik terutama bagi daerah kabupaten/kota yang memerlukan intervensi khusus sebagai daerah kepulauan tetapi terhambat oleh batasan definisi pada regulasi yang kurang mempertimbangkan realita kebutuhan daerah kepulauan, sehingga upaya percepatan pembangunan daerah kepulauan menjadi kurang komprehensif dan holistik.

Beberapa parameter seperti kesatuan sosio-ekonomi-geografis serta kesatuan gugusan pulau sulit untuk diukur dan dibuktikan sehingga berpotensi menimbulkan kekacauan dalam proses identifikasi dan klasifikasi apabila tidak dilakukan melalui metode ilmiah yang dapat dipertanggungjawabkan. Temuan lain ialah kelonggaran atau keketatan kriteria definisi akan mempengaruhi intervensi kebijakan yang 
diterapkan termasuk konsekuensi beban keuangan negara apabila tetap disertai dengan Dana Khusus Kepulauan atau Penerimaan Daerah Kepulauan dalam rangka Percepatan Pembangunan.

Berdasarkan hasil analisis ditemukan bahwa ketimpangan pembangunan berdasarkan variable indikator yang diamati antara daerah kepulauan dan non kepulauan tidak terlalu nyata, terdapat beberapa daerah kepulauan dengan karakter kota atau di suatu wilayah pulau yang memiliki indikator yang lebih baik dibandingkan daerah non kepulauan/pedalaman ada juga yang sebaliknya. Adapun ketimpangan pembangunan antara Jawa dan non Jawa, Kota dan bukan Kota, serta Indonesia Timur dan Indonesia Barat lebih jelas.

Selain itu ditemukan bahwa Dana Khusus Kepulauan akan memperlebar ketimpangan alokasi TKDD antardaerah. Sehingga penambahan DKK dalam struktur transfer ke daerah dan dana desa justru akan memicu permohonan dana khusus lainnya dengan berbagai argumentasi yang relevan untuk mengatasi tantangan pembangunan di daerah masing-masing, dana khusus daerah pedalaman atau dana adat, dana dan lain sebagainya untuk mengakomodasi kebutuhan yang beragam di pemerintahan daerah.

\subsection{Rekomendasi}

Jika Kebijakan Dana Khusus Kepulauan atau Penerimaan Daerah Kepulauan untuk Percepatan Pembangunan tetap dilanjutkan dalam RUU yang sedang disusun, maka perlu ada perbaikan kriteria alokasi dan perumusan definisi yang tepat untuk menghindari dampak negatif dari pemberian alokasi tambahan ini serta memastikan tercapainya tujuan yang diharapkan.

Alternatif lain dari Dana Khusus Kepulauan/Penerimaan Daerah Kepulauan untuk Percepatan Pembangunan salah satunya dapat melalui konvergensi DAK Tematik bagi wilayah kepulauan, mengingat sistem DAK relatif sudah berjalan dengan baik sehingga tidak akan menciptakan disrupsi yang terlalu besar bagi hubungan keuangan pusat-daerah. Pola lain selain dari Transfer ke Daerah perlu dioptimalkan terutama sumber pembiayaan yang berkaitan dengan laut, pesisir, pulau-pulau dan kepulauan (marine based financing) seperti instrument blue loan, blue bonds termasuk pendanaan kerja sama dalam pola transfer antardaerah

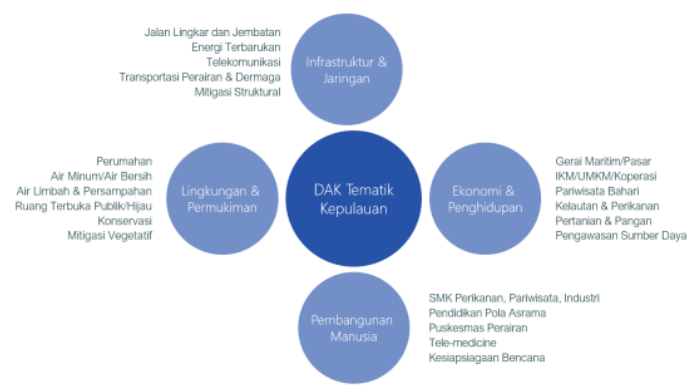

Gambar 19. Ilustrasi konvergensi DAK Tematik Kepulauan

Untuk mempercepat pembangunan daerah kepulauan, semestinya Daerah Provinsi tidak hanya yang 8, melainkan seluruh Daerah Provinsi yang memiliki pulau-pulau dan gugus kepulauan, mulai memikirkan bagaimana alternatif strategi pembangunan daerah kepulauan kedepannya. Dengan adanya ancaman Perubahan Iklim, kenaikan muka air laut, potensi hilangnya pulau-pulau, atau rusaknya biodiversitas karena pengasaman (asidifikasi), maka pola pembangunan yang dapat membantu terpenuhinya fondasi sosial (standar pelayanan minimum) dan menjaga supaya laju pembangunan tidak menembus batas-batas ekologis yang bisa membahayakan eksistensi/keberlangsungan pulau-pulau yang ada penting untuk dipertimbangkan.

Melalui upaya identifikasi potensi dan perancangan program yang baik, semestinya berbagai sumber-sumber pembiayaan 
pembangunan dapat dimobilisasi dalam rangka menyediakan pelayanan dasar yang memadai bagi masyarakat kepulauan dan dalam waktu yang bersamaan, mendorong geliat kegiatan perekonomian masyarakat di daerah kepulauan. Pendelegasian kewenangan pelayanan ekonomi skala kecil sektor kelautan dari Provinsi kepada Kabupaten Kota, yang tidak memicu timbulnya eksternalitas negatif yang ekstrateritorial (lintas wilayah) juga perlu didorong, supaya memudahkan pelaku usaha dalam menggerakan perekonomian masyarakat khususnya yang terkait dengan sektor kelautan dan perikanan. Pemerintah Daerah juga perlu mendobrak proses business as usual menjadi sebuah inovasi, yang ditempuh melalui proses kerjasama baik antar daerah kepulauan, maupun dengan daerah non kepulauan, atau dengan mitra pembangunan lainnya.

\section{Daftar Pustaka}

BNPB. (2016). Risiko Bencana Indonesia. Jakarta: Badan Nasional Penanggulangan Bencana.

BNPB. (2019). Indeks Risiko Bencana Indonesia 2015-2019. Jakarta, Indonesia. Retrieved from https://inarisk.bnpb.go.id/irbi

DJPK Kemenkeu. (2018). Portal Data DJPK. Retrieved from Kementerian Keuangan: http://www.djpk.kemenkeu.go.id/datada sar/dashboard

DPD RI. (2019, April 25). Naskah Akademik RUU tentang Daerah Kepulauan. Jakarta, DKI Jakarta, Indonesia. Retrieved from http://www.dpr.go.id/dokakd/dokumen /RJ1-20190425-125010-5297.pdf

DPR RI. (2020, July 24). Program Legislasi Nasional - RUU tentang Daerah Kepulauan. Retrieved from Dewan Perwakilan Rakyat Indonesia: http://www.dpr.go.id/uu/detail/id/417

DPR RI. (2020, July 24). Rancangan Undang Undang tentang Percepatan
Pembangunan Daerah Kepulauan.

Jakarta, DKI Jakarta, Indonesia. Retrieved from http://www.dpr.go.id/dokakd/dokumen /pembahasan_RUU_TENTANG_PERC EPATAN_PEMBANGUNAN__DAER AH_KEPULAUAN.pdf

Ismail. (2018, October 11). 80 Kepala Daerah di Indonesia Bahas Percepatan RUU Kepulauan. Tanjung Pinang, Kepulauan Riau, Indonesia. Retrieved July 24, 2020, from

https://batamtoday.com/tanjungpinang / read/ 103898/80-Kepala-Daerah-diIndonesia-Bahas-Percepatan-RUUKepulauan

Kelen, Y. A. (2017, February 24). Delapan Provinsi Kepulauan Sepakat Bentuk BKSDK. Retrieved July 24, 2020, from https://www.beritasatu.com/nasional/4 16125-delapan-provinsi-kepulauansepakat-bentuk-bksdk

Kumaat, J. C. (2011). Morfologi Gugusan Pulau Kecil (Archipelagic Islands) di Kabupaten Kepulauan Siau Tagulandang Biaro. Manado: Universitas Negeri Manado.

Nomor.net. (2020). Daftar Nama Pulau di

Seluruh Indonesia. Retrieved from nomor.net:

https://www.nomor.net/_kodepos.php? $\mathrm{i}=$ pulau-kodepos\&sby $=000000$

Santoso, M. A. (2009, Desember 4). Otonomi Daerah di Negara Kesatuan Republik Indonesia. Jurnal Ilmu Administrasi, 6(4), 391.

Stefanus, K. Y. (2011). Daerah Kepulauan sebagai Satuan Pemerintahan Daerah yang Bersifat Khusus. Jurnal Dinamika Hukum, 11(1), 99-111.

Undang Undang No 23 Tahun 2014 tentang Pemerintahan Daerah. (2014). Jakarta. Retrieved from 
https://pih.kemlu.go.id/files/UUo23201

4.pdf

Undang-undang Dasar Republik Indonesia Tahun 1945. (2002). Jakarta. Retrieved from http://www.dpr.go.id/jdih/uu 1945

Wollmann, H. (2007). Policy Evaluation and Evaluation Research. In F. Fischer, G. Miller, \& M. Sidney (Eds.), Handbook of Public Policy Analysis: Theory, Politics and Methods. New York: CRC Press Taylor \& Francis Group. 